\title{
LONG-TERM GROUNDWATER REGIME TRENDS IN THE AGRICULTURAL AREAS
}

Aurelija RUDZIANSKAITE், Institute of Water Resource Engineering, Faculty of Water and Land Management of Aleksandras Stulginskis University, Universiteto g. 10, LT-53361 Akademija, Kauno r., Lithuania, aurelija.rudzianskaite@asu.lt

\begin{abstract}
Long-term data on hydrological regime change of the groundwater situated in moraine sandy loam and peat in Lithuanian karst zone presented in the article. The aim of the paper was on the basis of long-term groundwater studies to determine the water level trends. Groundwater level fluctuations mainly dependent on the ground type. The nearest land surface groundwater level $(61-174 \mathrm{~cm})$ was measured in peat soil (well 1), in mineral soil (well 2) was deeper $(309-584 \mathrm{~cm}$ ). Correlation between data of the annual precipitation and groundwater level in mineral soils $\left(r^{2}=0.416, t_{a c t}=3.48>\right.$ t95\% $\left.=1.74\right)$ was more significant than in peat soils $\left(r^{2}=0.185\right.$, $\mathrm{t}_{\text {act. }}=1.96>\mathrm{t}_{95 \%}=1.74$ ). The highest fluctuations of groundwater level was determined in mineral soil (well 2). According to MannKendall test, the groundwater level significantly increased in February, April and December. Due to warmer winters decreased the duration and depth of the frost, frequent thaw, this cause increased feeding of aquifer in winter.
\end{abstract}

Keywords: groundwater level, karst zone, mineral soil, peat soil.

\section{INTRODUCTION}

The meteorological condition change is likely to respond closest to the Earth's surface occurring groundwater, this water is used many population in the rural (Giedraitiené, 2011; Arustiené, Kriukaite, 2011). In Lithuanian condition the most important fresh groundwater resource in the generation source of the natural condition is precipitation which fall in the aquifers and from this aquifer infiltrate in presure aquifers. Precipation infiltration to groundwater determined by the physical-geographical-geological and hydrogeological conditions in the region. Lithuania is situated in the humidity excess zone, precipitation significantly (about 2.6 times) exceed of their evaporation (Arustienè, Kriukaitè, 2011).

Atmosphere circulation changes determined other climatic characteristics. During this period significant changes in winter precipitation and in the thickness and duration of seasonal freezing were observed (Bukantis et al., 1998; Šimkevičiūtè, Bukantis, 2013; Rimkus et al., 2014). The mean depth of freezing decreased from 42 to $30 \mathrm{~cm}$. Because of the shorter duration of seasonal freezing, the period of active water circulation became longer and more frequent thaws increased winter surface run-off to karst lakes and sinkholes (Satkūnas et al., 2006). Increasing winter precipitation is result in increased river discharge during winter. Groundwater recharge increase in areas where the infiltration capacity is not currently exceeded, resulting in higher groundwater levels (Sonnenborg, 2015). Fluctuation of groundwater level depends on three main factors: hydrological or between-rivers regime, infiltration seasonality, and lithology and thickness of sediments in aeration zone (Juodkazis, 1992). The magnitude of the mean annual net precipitation was estimated to increase by up to $30 \%$, and the impact of this additional input of water was found to be highly dependent on the geological settings of the areas. In the area, characterized by sandy top soils and large interconnected aquifers, groundwater recharge increased significantly (van Roosmalen et al., 2007). The hot and dry summers, recurrent droughts, very uneven distribution of rainfall (over the year and in the territory) had a negative impact on groundwater resources (Arustienè, Kriukaite, 2011). Changes of groundwater level regime, especially seasonal, will not necessarily be useful for other elements of the environment to which groundwater is closely linked (Giedraitienè, 2011).

In the karst zone, where the hydraulic link between the surface and ground water is very good, even small sources of pollution may entain substantial changes of groundwater quality.

The aim of the paper is based on data of long-term groundwater studies is to evaluate the water level trends in the agricultural area of karst zone.

Copyright (C) 2017 The Authors. Published by Aleksandras Stulginskis University. This is an open-access article distributed under the terms of the Creative Commons Attribution License (CC-BY 4.0), which permits unrestricted use, distribution, and reproduction in any medium, provided the original author and source are credited. 


\section{MATERIALS AND METHODS}

North Lithuanian karst region is area (mainly Birzai, Pasvalys administrative districts and part of Panevezys district), where dissolution a gypsum formed underground cavity, and on the Earth surface are found old and new karst form (cavities, sinkholes, etc.). The North Lithuania karst region is located in the eastern part of the Baltic artesian basin. The active water change zone is up to $270 \mathrm{~m}$ thick and includes of the Upper Devonian. Variations in level and chemical composition of groundwater are determined by the rate of infiltration of precipitation. Ground collapse usually affects the Quaternary cover and permits ready recharge of surface water into the Upper Devonian aquifers. Areas with such intensive water circulation in open gypsum systems are referred to as the intensive karst zone (Juodkazis, 1992; Paukštys, 1996; Satkūnas et al., 2006). Water of the aeration zone mostly infiltrates through vertical fissures until it reaches either horizontal channels or impermeable soil layer. A large amount of rainwater is collected in the bottom of the sinkholes, which are open holes or filled with permeable deposits (Narbutas et al. 2001).

The studies of groundwater levels were carried out in moraine sandy loam and peat soil of active karst zone in 1995-2012 (Figure 1). The site is situated at the headwater of stream G-1 tributary of the Apascia, in Birzai district. The average surface inclination (between the watershed and riverbed) in G-1 basin is $0.5-1.5 \%$. The layers of gypsum-dolomite occur at 5-10 m depth from the soil surface (gypsum layers occur deeper) of the research site.

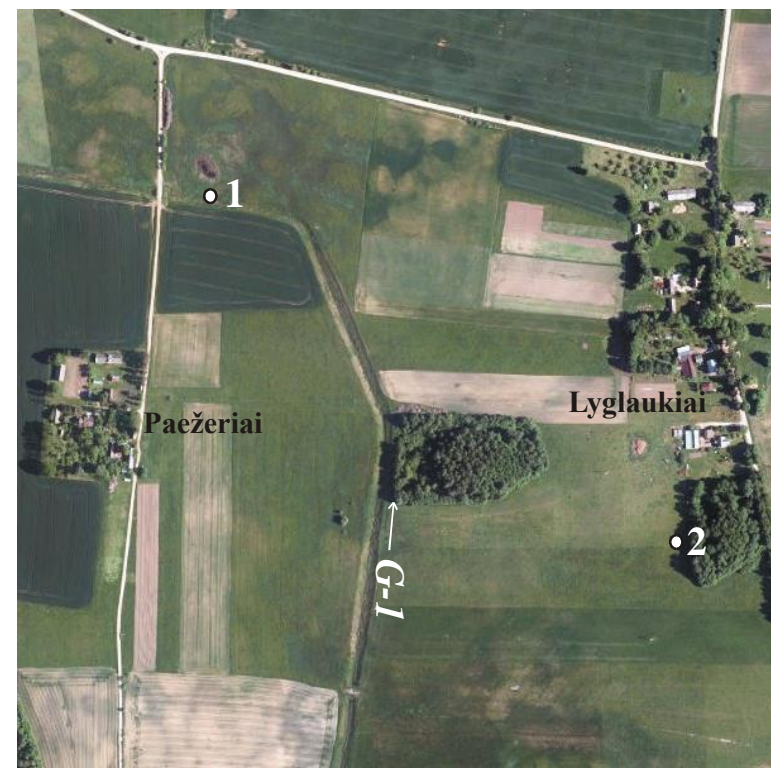

Figure 1. The scheme of study area: 1 - well

The figure 1 was made according to a digital map (https://www.maps.lt/).

The groundwater level was measured in different types of the soil: well 1 in the peat soil and well 2 in the mineral soil. The well $1(\mathrm{~h}=5.7 \mathrm{~m})$ was installed closest the stream G-1 and $20 \mathrm{~m}$ from the sinkhole; the well $2(\mathrm{~h}=8.8 \mathrm{~m})$ was installed in a pasture, near the few merged sinkholes.

The measurements of groundwater level were carried out once a week in 1995-2009. Automatic measurements of groundwater level were recorded daily since 2010, while the wells were equipped with automatic data loggers.

The meteorological data (precipitation and air temperature) were obtained from Birzai Meteorological Station, which is the nearest station to the study site. The average annual air temperature Climate Normal $(\mathrm{CN})$ is $5.9{ }^{\circ} \mathrm{C}(\mathrm{using}$ standard period 1961-1990 data (Manual of Lithuanian ..., 1992) and the average annual precipitation CN is $605 \mathrm{~mm}$ (Manual of Lithuanian ..., 1991).

Nonparametric Mann-Kendall partial (MK) test was applied to determine groundwater level data trend with a significance level of $\alpha<0.05$. Symbol (negative/positive) of Mann-Kendall test shows the trend direction. This test is wide used in environmental sciences (Libiseller, Grimvall, 2002; Stålnacke et al., 2003; Kaown et al., 2012). Linear regression was used to quantify the correlation of meteorological data to groundwater level.

\section{RESULTS AND DISCUSSION}

During study period the average annual air temperature ranged from $5.20{ }^{\circ} \mathrm{C}$ to $8.03{ }^{\circ} \mathrm{C}$ (Figure 2). The average annual air temperature was higher than $\mathrm{CN}$, except year 1996 which was on $0.9^{\circ} \mathrm{C}$ lower than $\mathrm{CN}$. The year $2000(7.89$ ${ }^{\circ} \mathrm{C}$ or $\left.134 \% \mathrm{CN}\right)$, as also $2008\left(8.03{ }^{\circ} \mathrm{C}\right.$ or $\left.136 \% \mathrm{CN}\right)$, was warmest. 

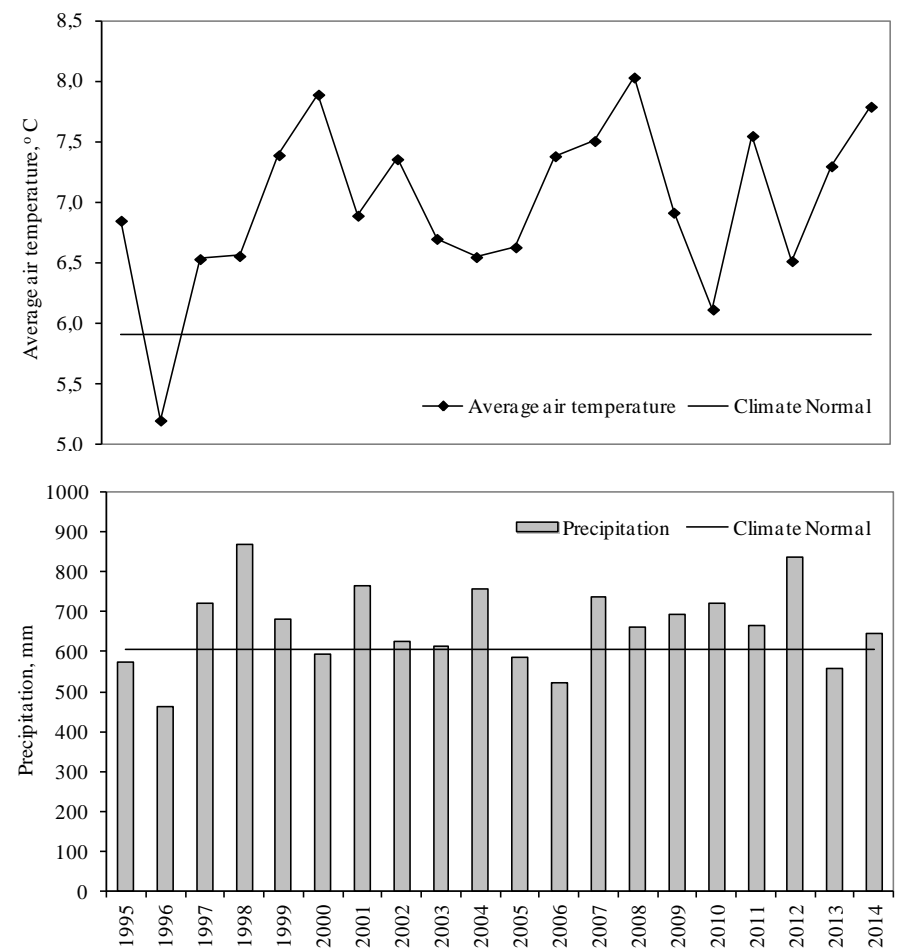

Figure 2. Dynamics of average annual air temperature and annual precipitation

The annual precipitation was 462-870 mm. Precipitation amount of the 6 years (1995 (95\% CN), $1996(76 \% \mathrm{CN})$, $2000(98 \% \mathrm{CN}), 2005(97 \% \mathrm{CN}), 2006(86 \% \mathrm{CN})$ and $2013(92 \% \mathrm{CN}))$ was lower than Climate Normal. The year 1998 $(144 \% \mathrm{CN})$ and $2012(139 \% \mathrm{CN})$ were marked by higher precipitation amount then $\mathrm{CN}$.

In the present study, the groundwater level $(61-174 \mathrm{~cm}$ ) was closer land surface in peat soil (well 1) compared to mineral soil (well 2) (Figure 3).

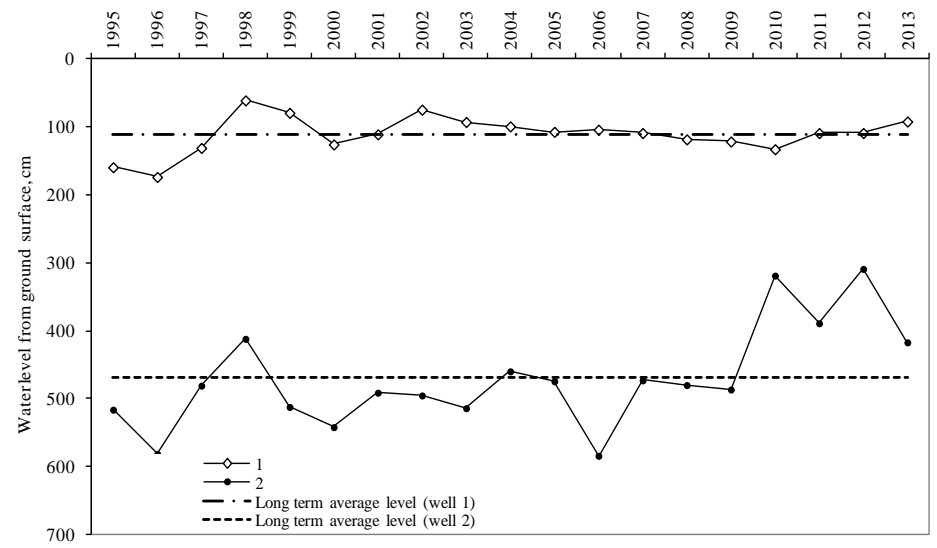

Figure 3. Fluctuations of groundwater level in wells

It has been observed if annual precipitation amount was higher, the groundwater level was closer to the ground surface. A closer correlation (determination coefficient $\left(r^{2}\right)=0.416$, actual Student's test $\left(t_{\text {act }}\right)=3.48>$ theoretical Student's test $\left.\left(t_{95 \%}\right)=1.74\right)$ between annual precipitation and groundwater level was estimated in mineral soils, while this relation was weaker $\left(r^{2}=0.185, t_{a c t .}=1.96>t_{95 \%}=1.74\right)$ in peat. The highest fluctuations of groundwater level measured in well 2 (mineral soil) compared to well 1 (peat). Presumably, this cause groundwater level variations (well 1) were determined by hydrophysical property of ground and influence of the stream. A stronger correlation $\left(r^{2}=0.16\right.$, $\mathrm{t}_{\text {act. }}=$ $1.77>t_{95 \%}=1.74 \%$ ) was estimated between average temperature and groundwater level in well 1 . The effect of meteorological conditions on groundwater level was determined only after a certain period of time. Depending on certain hydrogeological conditions, the groundwater temperature is be lated about 2-5 months compared to the air temperature (Giedraitienè, 1996).

The long-term average groundwater level was $111 \mathrm{~cm}$ in the peat (well 1) and it was $470 \mathrm{~cm}$ in the mineral soil (well 2). The groundwater level was 12 times (well 1) and in 6 times (well 2) lower than long-term average. According to Mann-Kendall test (MK), the groundwater level significantly increased in well 2 installed in mineral soil (Table 1). Chronological trend of average air temperature, precipitation, groundwater level in well 1 were statistically insignificant. 
Table 1. Mann-Kendall test for observation data of all study period

\begin{tabular}{|l|c|c|}
\hline & Mann-Kendall test (MK) & Q act. \\
\hline Temperature & 0.94 & 0.344 \\
\hline Precipitation & 0.45 & 0.649 \\
\hline Groundwater level in well 1 & -0.28 & 0.779 \\
\hline Groundwater level in well 2 & -2.62 & 0.009 \\
\hline
\end{tabular}

The results are significant on condition that $\alpha_{a c t .}<\alpha_{0.05}$.

Fluctuation of groundwater level had a seasonal character (Figure 4). The groundwater was closest to land surface in January - April. In May water level began to subside and the lowest subsided was in September, again it begins to rise up in October.

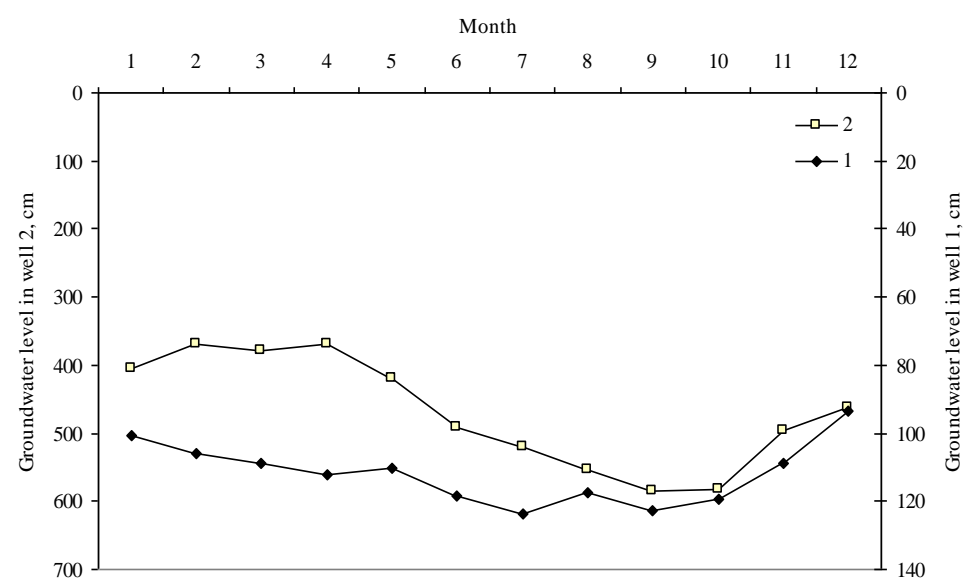

Figure 4. Seasonal distribution on groundwater level

The highest groundwater level in 2005-2010 was in the spring, usually in March-April, and the minimum was in September and October (Giedraitine, 2011). In river valleys where groundwater is closely interrelated to surface water, amplitudes of water level fluctuations much depend on surface water fluctuations and distance to a water body. The most significant groundwater fluctuations are observed in places where the thickness of aeration zone reaches 3-4 $\mathrm{m}$ (Giedraitienè, Domaševičius, 1996). Seasonal groundwater fluctuations depend on the infiltration nutrition in different seasons of the year. The intensity of infiltration nutrition depends on the meteorological factors, first of all on the air temperature and precipitation amount (Domaševičius et al., 1996).

Statistically significant trend in groundwater level fluctuation were confirmed in both wells in February and in well 2 in April and December. Statistically significant trend in precipition was detected in December and average air temperature - in November (Table 2). Due to warmer winters decreased the duration and depth of the frost, frequent thaw, this cause increased feeding of aquifer in winter.

Table 2. Significance of temporal changes in months

\begin{tabular}{|c|c|c|c|c|c|c|c|c|}
\hline \multirow{2}{*}{ Months } & \multicolumn{2}{|c|}{ Air temperature } & \multicolumn{2}{|c|}{ Precipitation } & \multicolumn{2}{|c|}{ Well 1 } & \multicolumn{2}{c|}{ Well 2} \\
\cline { 2 - 10 } & MK test & $\alpha_{\text {act. }}$ & MK test & $\alpha_{\text {act. }}$ & MK test & $\alpha_{\text {act. }}$ & MK test & $\alpha_{\text {act. }}$ \\
\hline January & -0.63 & 0.53 & -0.14 & 0.89 & -1.33 & 0.18 & -1.89 & 0.06 \\
\hline February & -1.57 & 0.11 & -0.73 & 0.46 & $\mathbf{- 2 . 0 2}$ & $\mathbf{0 . 0 4}$ & $\mathbf{- 2 . 2 1}$ & $\mathbf{0 . 0 3}$ \\
\hline March & -0.81 & 0.42 & 0.14 & 0.89 & 0.24 & 0.81 & -1.85 & 0.06 \\
\hline April & -0.07 & 0.94 & 0.56 & 0.57 & -0.99 & 0.32 & $\mathbf{- 2 . 3 9}$ & $\mathbf{0 . 0 2}$ \\
\hline May & 1.86 & 0.06 & -0.80 & 0.42 & 0.15 & 0.88 & -1.63 & 0.10 \\
\hline June & 0.17 & 0.86 & -0.59 & 0.55 & -0.93 & 0.35 & -0.16 & 0.87 \\
\hline July & 1.54 & 0.12 & 0.73 & 0.46 & -1.17 & 0.24 & -0.14 & 0.89 \\
\hline August & 0.49 & 0.62 & 1.05 & 0.29 & -0.55 & 0.58 & -0.05 & 0.96 \\
\hline September & 1.72 & 0.09 & 0.63 & 0.53 & -0.45 & 0.65 & -0.91 & 0.36 \\
\hline October & -0.03 & 0.97 & -0.42 & 0.67 & -0.61 & 0.54 & -1.07 & 0.28 \\
\hline November & $\mathbf{2 . 1 1}$ & $\mathbf{0 . 0 4}$ & 1.47 & 0.14 & -1.24 & 0.22 & -1.40 & 0.16 \\
\hline December & 1.51 & 0.13 & $\mathbf{2 . 0 3}$ & $\mathbf{0 . 0 4}$ & -1.58 & 0.11 & $\mathbf{- 2 . 0 7}$ & $\mathbf{0 . 0 4}$ \\
\hline
\end{tabular}

Results in bold type are statistically significant at the significance level $\alpha_{0.05}$

The projected of the moisture amount increasing especially in the winter-spring season, consist with the rise of groundwater level periods. Due to rising groundwater level increases its sensitivity to pollution, i.e. increasing the risk that it will fall polluting substances (Arustienè, Kriukaite, 2011). 


\section{CONCLUSIONS}

1. During study period groundwater level fluctuations are mainly dependent on the ground type. The nearest land surface groundwater level $(61-174 \mathrm{~cm})$ was measured in peat (well 1), in mineral soil (well 2) was deeper $(309-584 \mathrm{~cm})$.

2. Correlation between data of the annual precipitation and groundwater level was estimated in mineral soils $\left(r^{2}=0.416\right.$, $\left.t_{\text {act. }}=3.48>t_{95 \%}=1.74\right)$ was more significant than in peat soils $\left(r^{2}=0.185, t_{\text {act. }}=1.96>t_{95 \%}=1.74\right)$. The widest fluctuations of groundwater level occurred in mineral soil (well 2).

3. According to Mann-Kendall test, the groundwater level significantly increased in February, April and December. Due to warmer winters decreased the duration and depth of the frost, frequent thaw, this cause increased feeding of aquifer in winter.

\section{REFERENCES}

1. Arustienè, J., Kriukaitè, J. 2011. Climate cange impact on groundwater resources. In: Kadūnas K. (ed) Lietuvos požeminio vandens monotoringas 2005-2010 m. ir kiti hidrogeologiniai darbai. Lietuvos Geologijos Tarnyba: Vilnius. Lithuania, pp. 84-89 [In Lithuanian]

2. Bukantis, A., Rimkutè, L., Kazakevičius, S. 1998. Atmospherics precipitation. In: Bukantis, A., Kazakevičius, S., Korkutis, P., Matukonienè, V. (eds) Klimato elementų kintamumas Lietuvos teritorijoje. Geografijos institutas, Vilnius, Lithuania, pp. 19-41 [In Lithuanian]

3. Domaševičius, A., Giedraitienè, J., Arustienè, J. 1996. Groundwater monitoring in Lithuania 1995. Lietuvos geologijos tarnyba, Vilnius, Lithuania. [In Lithuanian]

4. Giedraitienè, J. 1996. The regularities of temperatures in soils. In: Požeminio vandens monitoringas Lietuvoje 1946-1996, pp. 23-25. [In Lithuanian].

5. Giedraitienè, J. 2011. Change of groundwater level regime associated with meteorological condition. In: Kadūnas K. (ed). Lietuvos požeminio vandens monotoringas 2005-2010 m. ir kiti hidrogeologiniai darbai. Lietuvos Geologijos Tarnyba, Vilnius, Lithuania, 13-22 [In Lithuanian].

6. Giedraitienè, J.; Domaševičius, A. 1996. The investigations of groundwater levels. In: Požeminio vandens monitoringas Lietuvoje 1946-1996, pp. 15-22. [In Lithuanian].

7. Juodkazis V. 1992. Lithuanian karst: hydrogeology and groundwater protection. Geologija, 13, 195 p. [In Lithuanian]

8. Hirsch, R. M., Slack, J. R. 1984. A nonparametric trend test for seasonal data with serial dependence. Water Resources Research Vol. 20, Iss. 6, pp. 727-732. https://doi.org/10.1029/WR020i006p00727

9. Kaown, D., Hyun, Y., Bae, G.-O., Oh, C.W., Lee, K.-K. 2012. Evaluation of spatio-temporal trends of groundwater quality in different land uses using Kendall test. Geosciences Journal, Vol. 16(1), pp. 65-75. https://doi.org/10.1007/s12303-012-0009-4

10. Libiseller C., Grimvall A. (2002) Performance of partial Mann - Kendall tests for trend detection in the presence of covariates. Environmetric, Vol. 13, pp. 71-84. https://doi.org/10.1002/env.507

11. Manual of Lithuanian Climate. Air temperature. 1992. Lietuvos hidrometeorologijos valdyba. Vilnius. Lithuania. [In Lithuanian].

12. Manual of Lithuanian Climate. Precipitation. 1991. Lietuvos hidrometeorologijos valdyba. Vilnius, Lithuania, [In Lithuanian].

13. Narbutas, V., Linčius, A., Marcinkevičius, V. 2001. Karst of the Devonian rocks and the problems of environment protection in North Lithuania. Agora, Vilnius. [In Lithuanian].

14. Paukštys, B. 1996. Hydrogeology and groundwater protection problems in karst region of Lithuania. Geology Society of Lithuania, Vilnius.

15. Rimkus, E., Kažys, J., Butkutè, S., Gečaitè, I. 2014. Snow cover variability in Lithuania over the last 50 years and its relationship with large-scale atmospheric circulation. Boreal Environment Research, Vol. 19, pp. 337-351.

16. van Roosmalen, L., Christensen, B. S. B., Sonnenborg, T. O. 2007. Regional differences on climate change impacts on groundwater and stresam disharge in Denmark. Vadose Zone Journal, Vol. 6, pp. 554-571. https://doi.org/10.2136/vzj2006.0093

17. Satkūnas, J., Taminskas, J., Dilys, K. 2006. Geoindicators of changing landscapes - an example of karst development in North Lithuania. Geological Quarterly, Vol. 50, Iss. 4, pp. 457-464.

18. Stålnacke, P., Grimvall, A., Libiseller, C., Laznik, M., Kokorite I. 2003. Trends in nutrient concentrations in Latvian rivers and the response to the dramatic change in agricuture. Journal of Hydrology, Vol. 283, pp. 184-205. https://doi.org/10.1016/S00221694(03)00266-X

19. Sonnenborg, T.O. 2015. Projected Change-Hydrology. In: The BACC II Author Team (eds). Second Assessment of Climate Change for the Baltic Sea Basin. Regional Climate Studies. Springer, Cham pp. 235-241. https://doi.org/10.1007/978-3-319-16006$\underline{1 \_12}$

20. Šimkevičiūtè, A., Bukantis, A. 2013. Severe and catastrophic meteorological events in Lithuania in the cold half of the year in 1971-2010. Geografija, No. 49, pp. 33-44. 